\title{
Evaluation of Groundwater Quality and Suitability for Drinking and Irrigation Purposes Using Hydrochemical Approach: The Case of Raya Valley, Northern Ethiopia
}

\author{
Gebrerufael Hailu Kahsay $^{1 *}$, Tesfamichael Gebreyohannes ${ }^{2}$, Fethanegest Woldemariyam ${ }^{2}$ \\ and Tesfa-alem Gebreegziabher Emabye ${ }^{3}$ \\ ${ }^{1}$ Institute of Geo-information and Earth Observation Sciences, Mekelle University P.O.Box 231, \\ Mekelle, Ethiopia (*rufaelkh@gmail.com). \\ ${ }^{2}$ School of Earth Sciences, Mekelle University, P.O.Box.231, Mekelle, Ethiopia. \\ ${ }^{3}$ Institute of Water and Environment, Mekelle University, P.O. Box 231, Mekelle, Ethiopia.
}

\begin{abstract}
Groundwater is a vital source of water for domestic and agricultural activities in Raya valley due to non-perennial flow of surface water.Thus the present study aims to evaluate the groundwater quality and assess its suitability for drinking and irrigation purposes. A total of 137 groundwater samples were examined for various physico-chemical parameters to evaluate the quality and suitability of groundwater for the intended purposes. Piper-Hill diagram was adapted to infer hydro-geochemical facies and water types. The suitability of groundwater for drinking purpose was evaluated by comparing the analytical results of different water quality parameters to the Ethiopian standard as well as World Health Organization Standards (WHO, 2006). Salinity, sodicity and related parameters were considered to evaluate the suitability of the groundwater for irrigation use. The dominant water types are magnesium bicarbonate and sodium-calcium bicarbonate. The hydrochemistry of the groundwater changes from $\mathrm{Mg}-\mathrm{Ca}-\mathrm{HCO}_{3}$ dominance at the foot of volcanic hills to $\mathrm{Ca}-\mathrm{Mg}-\mathrm{Na}-\mathrm{HCO}_{3}$ and $\mathrm{Ca}-\mathrm{Na}-\mathrm{Mg}-\mathrm{HCO}_{3}$ at the valley floor. On the basis of total hardness, $46 \%$ of the water samples in Raya valley fall in the very hard water class whereas, based on TDS values $95 \%$ of the water samples are found to be permissible for drinking. With the exception of three constituents $\left(\mathrm{Mg}^{2+}, \mathrm{Ca}^{2+}\right.$ and $\left.\mathrm{K}^{+}\right)$, all other analyzed constituents in groundwater are within the established standards of Ethiopia. Water suitability for irrigation indicates that the groundwater fall in the range of good to permissible, however, higher salinity, magnesium hazard and low permeability index restricted its suitability in southeastern parts of the study area.
\end{abstract}

Keywords: Water quality, SAR, Irrigation and drinking suitability, Raya Valley, Ethiopia.

\section{INTRODUCTION}

Water naturally contains several different dissolved inorganic constituents. Among which calcium, magnesium, sodium and potassium (cations); and chloride, sulphate, carbonate, and bicarbonate (anions) constitute about $90 \%$ of the total dissolved solids (TDS) in water (Fetter, 2001). Minor constituents include iron, strontium (cations); nitrate, phosphate, and fluoride (anions). Trace constituents like $\mathrm{As}, \mathrm{Cr}, \mathrm{Pb}, \mathrm{Mn}, \mathrm{U}$ etc, will be less than $0.1 \mathrm{mg} / \mathrm{l}$ in concentration. Water quality is a consequence of the natural physical and chemical state of the 
water as well as any alterations that may have occurred as a consequence of anthropogenic activities (Venkateswaran et al., 2011). Analysis of water chemistry is used to describe the physical, chemical and biological characteristics of the water in respect to its suitability for particular purpose. Water chemistry data can also be used to infer flow directions, identify sources of recharge to groundwater and estimate amount of recharge (Anderson and Woessner, 1992).

Groundwater is generally considered to be much cleaner than surface water. However, several factors such as discharge of industrial, agricultural and domestic waste water, land use practices, geological formation, rainfall patterns and infiltration rate affect the groundwater quality (Patil, 2010). The main reason for the assessment of hydrochemistry is to understand processes that determine groundwater quality, both natural and anthropologic, in order to verify whether the observed water quality is suitable for an intended use.

Raya valley which is one of the groundwater based irrigation development areas in Tigray region is selected for the present study. Groundwater is a vital source of water for domestic and agricultural activities in Raya valley due to non-perennial flow of surface water during dry periods. About 250 deep wells are drilled in the area so far for irrigation and domestic water supply purposes. Moreover, a study by WWSDE (2008) recommended increasing the number of wells to 610 for developing the Raya valley pressured irrigation system.

The groundwater potential for irrigation at the Raya valley has been the focus of study/research since 1996 owing to the expected high groundwater potential. It has been studied by different governmental and non-governmental institution and academicians (REST, 1996; Hailu, 2010; Mohammed sultan, 2010; Tadesse et al., 2015, Nadew, 2003; WWDSE, 2008; Gebre Egziabher, 2012; Hussein, 2011; Ayenew et al., 2013 etc.). The previous studies were mainly focused on the potential, development and evaluation of the hydrochemistry of the groundwater in the area. However, the spatial extent of groundwater suitability for both drinking and irrigation purposes in comparison to guidelines and criteria was not been addressed by these studies. Therefore, the present study is carried out to evaluate the spatial distribution of groundwater quality and its suitability for irrigation and domestic water supply purposes supplementing the previous efforts with additional water samples. 


\subsection{Study Area}

The study site is located in northern Ethiopia, Tigray regional state, at about $170 \mathrm{~km}$ south of the region's capital Mekelle (Fig 1). From regional point of view, the area is considered as part of interconnected valleys of the Ethiopian rift system (Fig 2) with an area of about $2500 \mathrm{~km}^{2}$. Raya valley is bounded by the North-Western Ethiopian Plateau in the west and the Afar Rift in the east. The transition to the Afar depression is marked by a low range of volcanic hills which form the eastern boundary of the study area. Locally, Raya valley is an elongated intermountain graben filled with Quaternary sediments bordered to the east and west by rugged volcanic mountains. It is bounded by Korem Mountains in the west, Chercher Mountains in the east and by surface water divide near Kobo town separating the Alamata sub-basin and the Golina subbasin in the south.

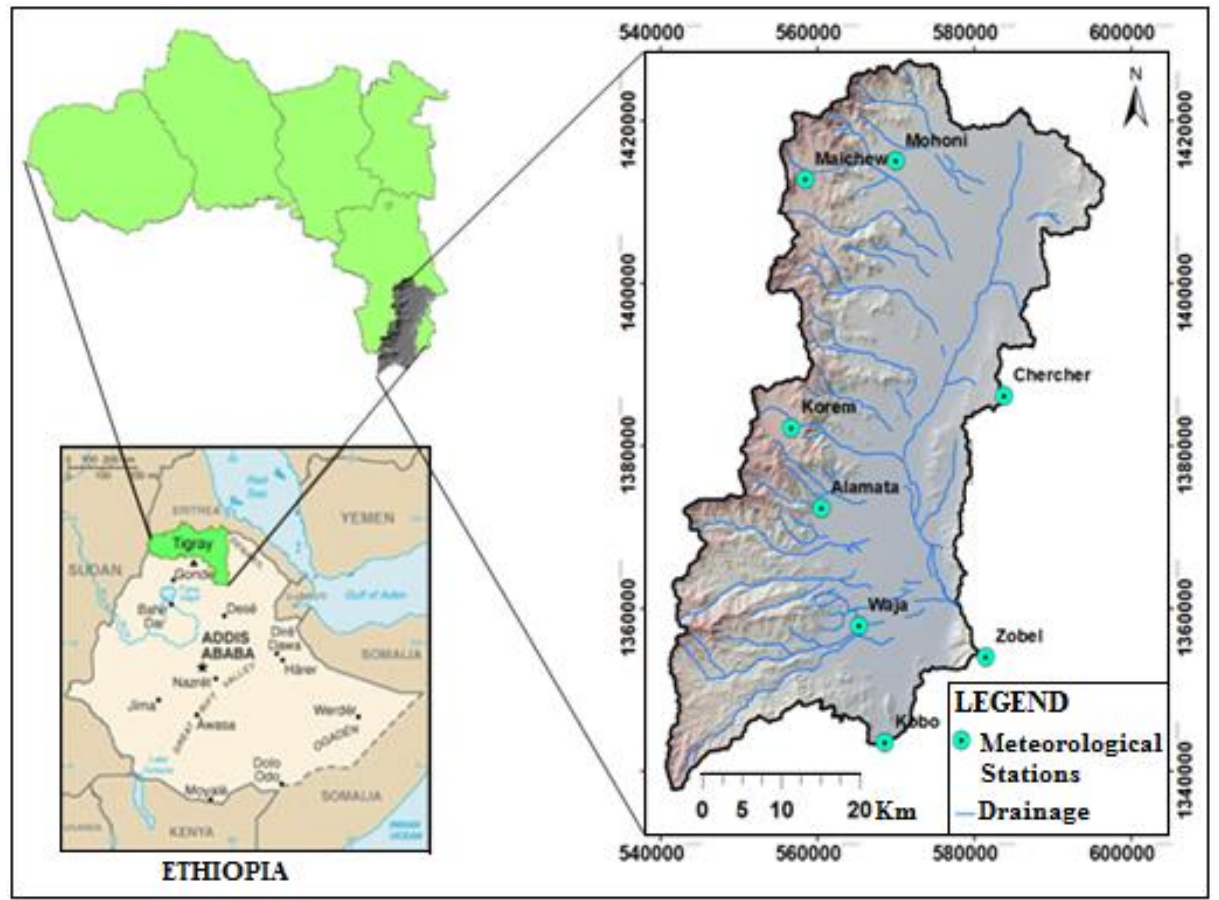

Figure 1. Location of the study area.

Average altitude in the Raya valley ranges from $1382 \mathrm{~m}$ (valley floor) to $3688 \mathrm{~m}$ a.m.s.1 in the western mountain peaks (Fig 3a). Geologically, the study area is characterized by the Tertiary volcanics, predominantly basalt in the highlands and Quaternary sediments in the valley plain.

Raya valley is characterized by an erratic, bimodal rainfall pattern with main rainy season lasting from late June to early September. The highest rainfall record occurs in July and August, 
whereas the short spring rainy season extends from February to March. Average monthly temperature of the Raya valley varies from a minimum average of $4.7^{\circ} \mathrm{C}$ in the Korem plateaus to a maximum average of $35.5^{\circ} \mathrm{C}$ at Waja lowlands.

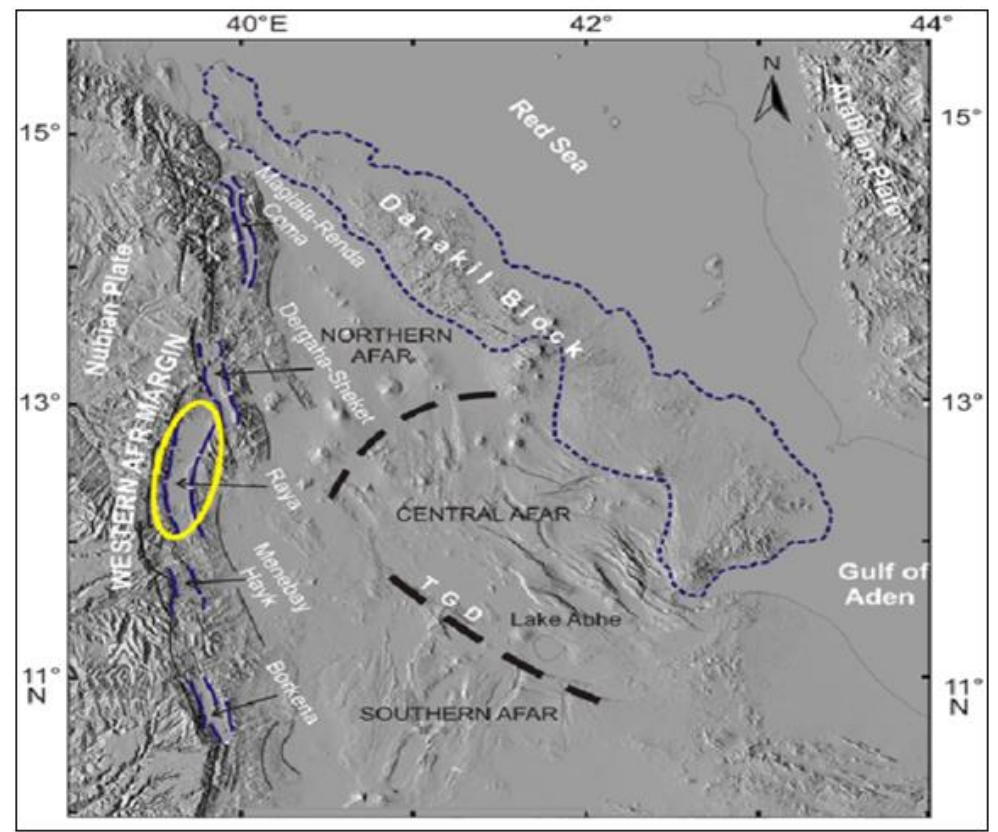

Figure 2. Relief map of Afar area (after Tesfaye et al., 2003).

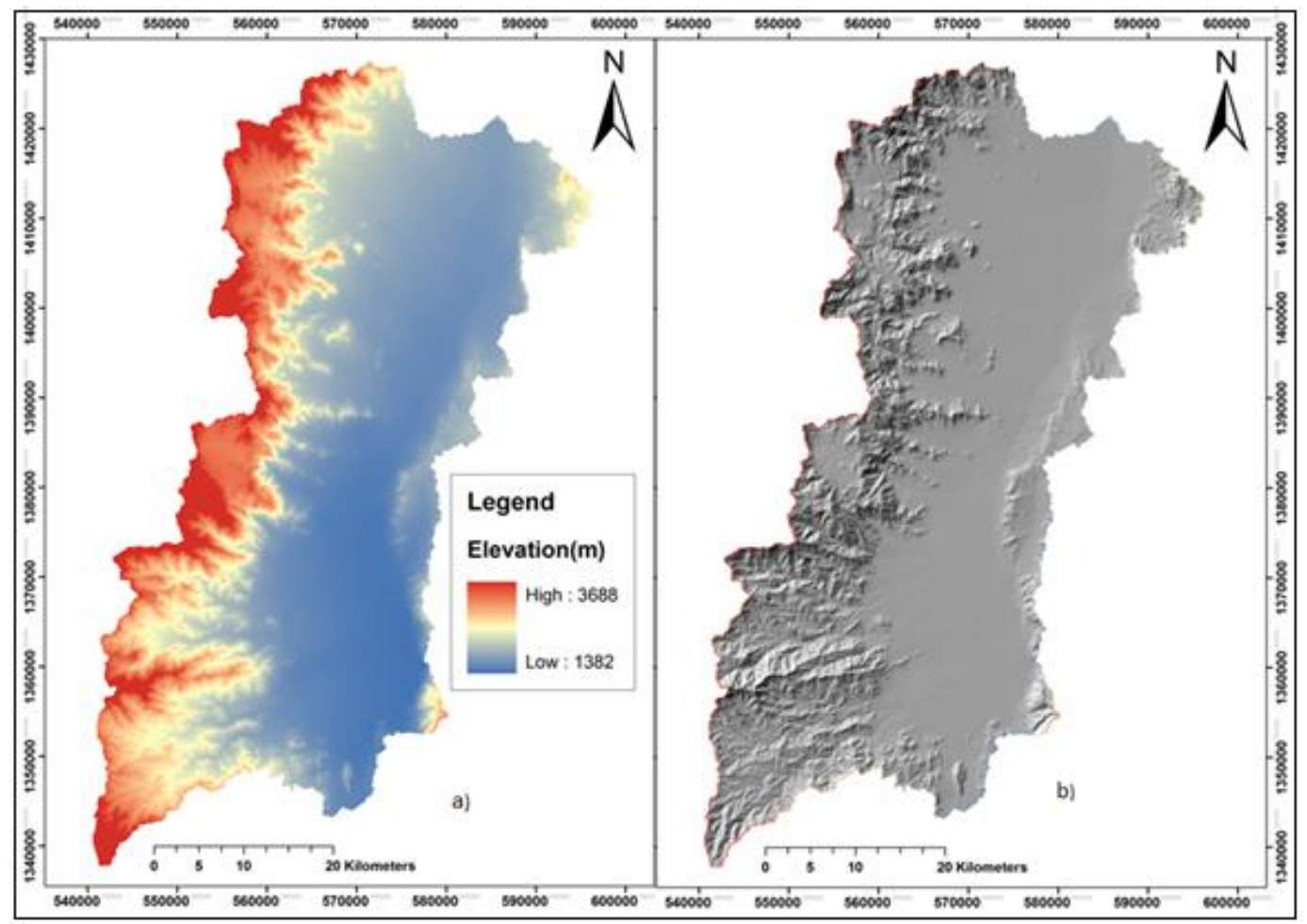

Figure 3. Elevation range (a) shaded relief map (b) Raya valley. 


\section{METHODOLOGY}

\subsection{Data Source and Sampling}

30 groundwater samples were collected as part of the present study during the field work conducted during 2015 and 2018 in Raya valley. The samples were filtered using $0.45 \mu \mathrm{m}$ pore size membrane filters and stored in polyethylene bottles that were initially washed with nitric acid and rinsed carefully with distilled water. For the assessment of groundwater quality, the published data of Water Works Design and Supervision Enterprise (WWSDE, 2008) on 107 groundwater from Raya valley is also used. All groundwater sample locations, previous (WWSDE, 2008) and present study, total of 137, are shown in figure 4.

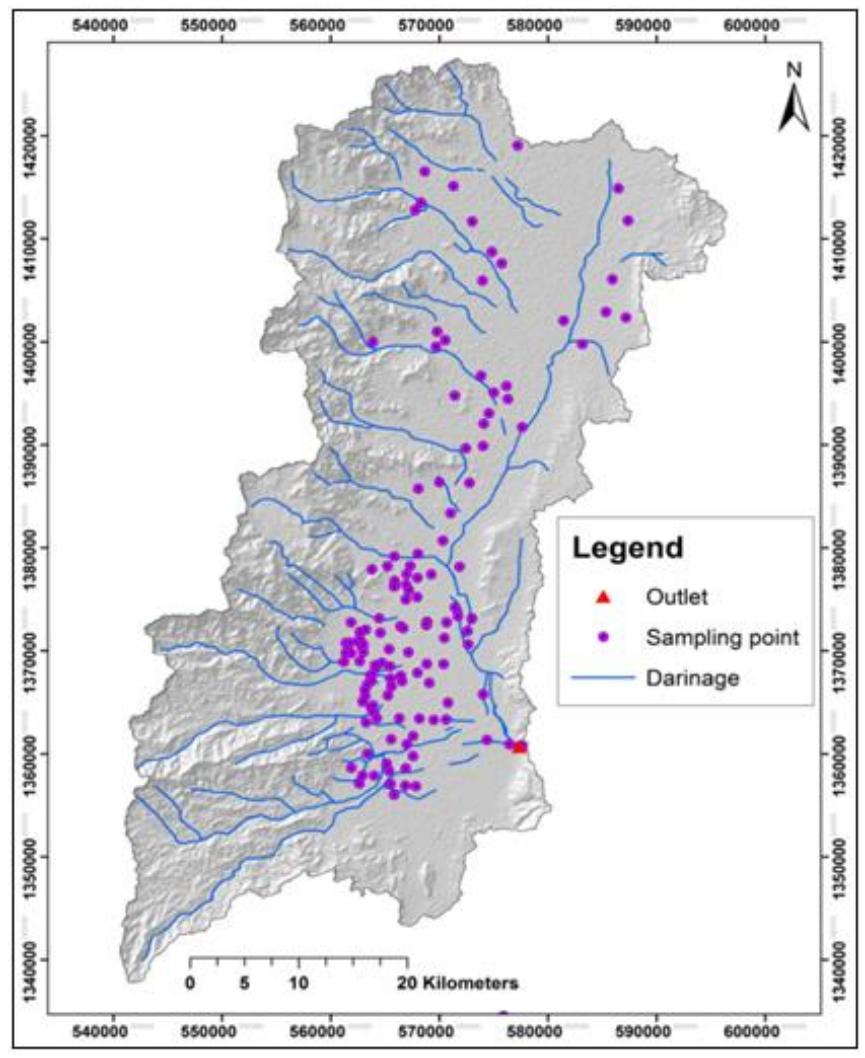

Figure 4. Groundwater sample locations.

A second set of sample from each sampling point was collected and acidified by adding ultrapure hydrochloric acid for cation measurements. Parameters like $\mathrm{pH}$, conductivity and temperature were measured at the time of sampling with compact digital precision meter (Multi 3410) probe field kit, whereas major ions were analyzed in the geochemical laboratory of Technical university of Darmstadt. Major cations such as $\mathrm{Ca}^{2+}$ and $\mathrm{Mg}^{2+}$ were analyzed by 
titration method, $\mathrm{Na}^{+}$and $\mathrm{K}^{+}$by flame photometer, chloride by titration method and $\mathrm{NO}_{3}{ }^{-}, \mathrm{F}^{-}$, $\mathrm{SO} 4^{2-}$ by spectrophotometer.

\subsection{Reliability Check}

To evaluate the data quality, the accuracy of the chemical analysis results of both the new and preexisting was checked with the anion-cation balance (Equation 1). The principle of the anioncation balance is that the sum of cations and sum of anions are equal because the solution must be electrically neutral. In an electrically neutral solution, the sum of the cations should be equal to the sum of anions in milli- equivalent per liter (Hounslow, 1995).

$$
\text { Electroneutrality }(\%)=\frac{\sum \text { Cations }-\sum \text { Anions }}{\sum \text { Cations }+\sum \text { Anions }} * 100
$$

Based on the electro neutrality, analysis of water samples with a percent balance error < $\pm 5 \%$ is regarded as acceptable (Fetter, 2001). The cations and anions balance results of the water samples analysis from Raya valley are found to be reliable as the charge balance error from $95 \%$ of the samples was within the accepted limits of $< \pm 5 \%$. Analysis data of 137 groundwater samples were used to determine groundwater chemistry in Raya valley.

\section{3. GIS-Analysis}

Spatial distribution maps of the various physico-chemical parameters were carried out using Arc Map GIS10.1 software with spatial analyst module. Kriging interpolation technique was applied in order to interpolate the point data of the physico-chemical parameters to estimate values between measurements. Kriging is selected because it is an advanced geostatistical procedure that generates an estimated surface from a scattered set of point values. Given sufficient data, Kriging produce better estimates than the other interpolation methods because the method takes explicit account of the effect of random noise (Azpurua and Ramos, 2010).

\subsection{Hydrochemical Facies}

Facies are recognizable parts of different characters belonging to any geologically related system. Hydrochemical facies are distinct zones that possess cation and anion concentration categories. Dissolved constituents in water can provide indications on its geologic history through which it has passed and its mode of origin within the hydrologic cycle (Freeze and Cherry 1979). Different graphical presentations were used to infer hydro-geochemical facies from physicochemical parameters of water sample analysis. Zaporozhe (1972) has summarized the various methods of data presentation. Presentation of chemical analysis in graphical form 
makes understanding of complex groundwater system simpler and quicker. Methods of representing the chemistry of water like Collin's bar diagram, radiating vectors of Maucha (1940), and parallel and horizontal axes of Stiff (1940), have been used in many parts of the world to show the proportion of ionic concentration in individual samples.

In this study, Piper-Hill diagram (Piper, 1953) was adapted to infer hydro-geochemical facies of the Raya valley. The Piper-Hill diagram consists of three different fields, two triangular fields one for plotting cations and the other for plotting anions and one diamond-shaped field (Figure 5).The cations and anion fields are combined to show a single point in a diamond-shaped field, from which inference is drawn on the basis of hydro-geochemical facies concept. These trilinear diagrams are useful in bringing out chemical relationships among groundwater samples. According to Hounslow (1995), the position of an analysis that is plotted on a piper diagram can be used to make tentative conclusion as to the origin of the water represented by the analysis.

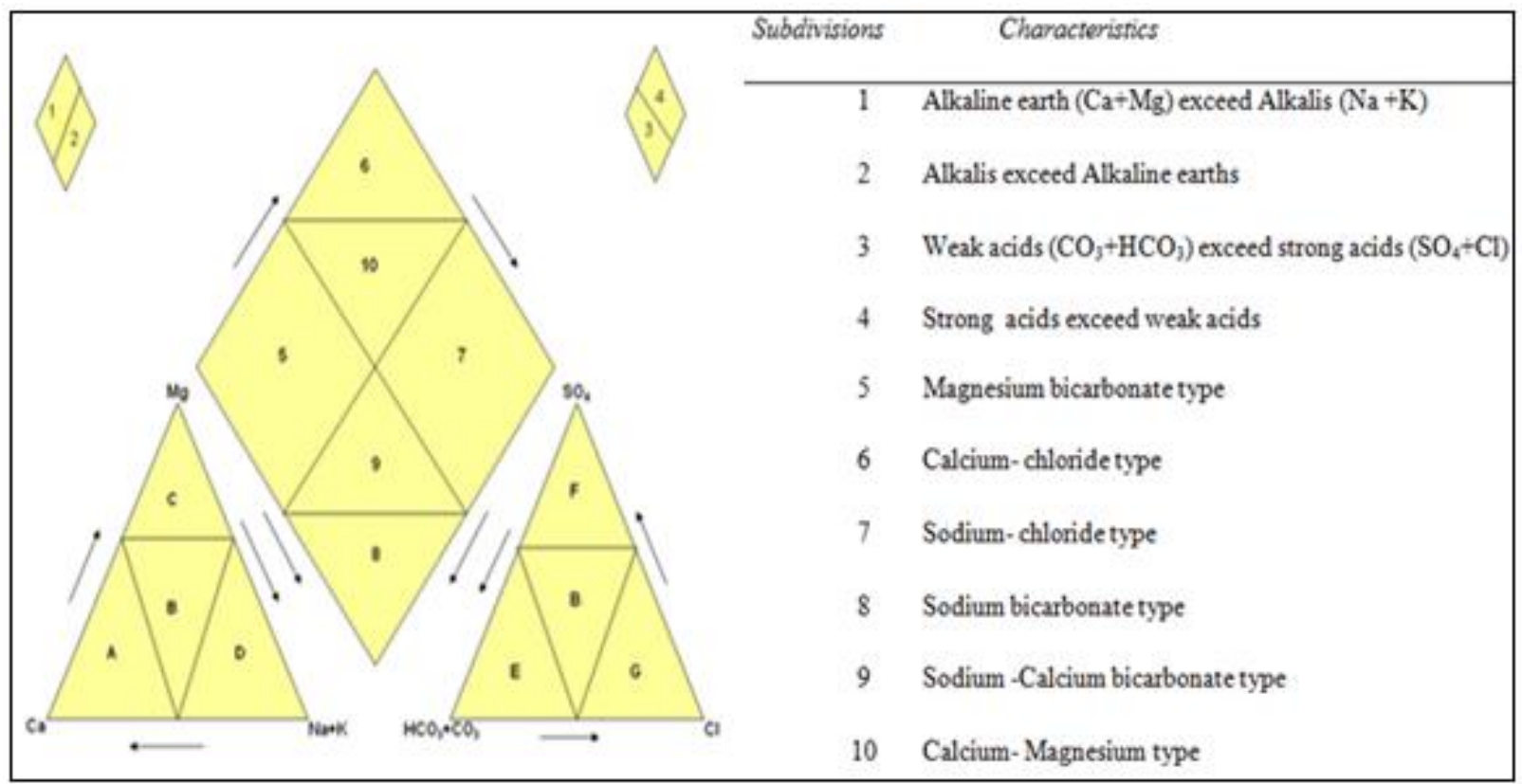

Figure 5. Classification diagram for anion and cation facies in the form of major-ion percentages.

\subsection{Groundwater Suitability}

The suitability of groundwater for drinking purpose was evaluated by comparing the analytical results of different water quality parameters to the Ethiopian standard (ES 261:2001) as well as World Health Organization Standards (WHO, 2006) guidelines. Salinity, sodicity and related parameters were considered to evaluate the suitability of the groundwater for irrigation use. 
Water salinity is assessed using electric conductivity whereas water sodicity of the area is assessed by sodium percent $(\mathrm{Na} \%)$ and Sodium absorption ratio (SAR). Salinity and sodium hazards of the study area are also assessed based on the salinity classification standard of the US Department of Agriculture diagram or Wilcox plots (Wilcox, 1955).

\section{RESULTS AND DISCUSSION}

\subsection{Hydrochemical Facies}

Summary of the statistics of the analytical results for the groundwater samples in the study area are presented in the table 1 . The major dissolved cations in the groundwater are $\mathrm{Mg}^{2+}, \mathrm{Ca}^{2+}$ and $\mathrm{Na}^{+}$with lower levels of $\mathrm{K}^{+}$and the major dissolved anions include $\mathrm{HCO}_{3}{ }^{-}, \mathrm{SO}_{4}{ }^{2-}$ and $\mathrm{Cl}^{-} . \mathrm{Mg}^{2+}$ and $\mathrm{Ca}^{2+}$ are the dominant cations in the water from western part of the study area while, $\mathrm{Na}^{+}$ dominate in the samples located in the valley floor.

Table 1. Summary statistics of major ion concentrations of the analyzed water samples.

\begin{tabular}{|c|c|c|c|c|c|c|}
\hline Constituent & Minimum & Maximum & Range & Median & Mode & Mean \\
\hline $\mathrm{EC}\left(\mu \mathrm{S} \mathrm{cm}^{-1}\right)$ & 308 & 3800 & 3492 & 681 & 539 & 813 \\
\hline $\operatorname{TDS}\left(\mathrm{mg} \mathrm{l}^{-1}\right)$ & 204 & 2437 & 2233 & 434 & 396 & 514 \\
\hline Hardness (as CaCO3mg $\mathrm{l}^{-1}$ ) & 25 & 2402 & 2377 & 294 & 202 & 327 \\
\hline $\mathrm{pH}$ & 7 & 8 & 2 & 8 & 8 & 8 \\
\hline $\mathrm{Ca}^{2+}\left(\mathrm{mg} \mathrm{l}^{-1}\right)$ & 5 & 168 & 163 & 62 & 55 & 66 \\
\hline $\operatorname{Mg}^{2+}\left(\mathrm{mg} \mathrm{l}^{-1}\right)$ & 2 & 565 & 563 & 30 & 25 & 42 \\
\hline $\mathrm{Na}^{+}\left(\mathrm{mg} \mathrm{l}^{-1}\right)$ & 1 & 940 & 939 & 51 & 33 & 72 \\
\hline $\mathrm{K}^{+},\left(\mathrm{mg} \mathrm{l}^{-1}\right)$ & 0 & 218 & 218 & 2 & 1 & 5 \\
\hline $\mathrm{HCO}^{-}\left(\mathrm{mg} \mathrm{l}^{-1}\right)$ & 34 & 1127 & 1093 & 373 & 281 & 391 \\
\hline $\mathrm{CI}^{-}\left(\mathrm{mg} \mathrm{l}^{-1}\right)$ & 6 & 576 & 570 & 26 & 16 & 50 \\
\hline $\mathrm{SO}^{2-}\left(\mathrm{mg} \mathrm{l}^{-1}\right)$ & 1 & 1820 & 1820 & 24 & 4 & 68 \\
\hline
\end{tabular}

The dominancy of these cation- anion composition is mainly associated with the volcanic rock minerals present in the study area. Composition of the water in the area is mainly controlled by the chemical weathering of silicate minerals which are the major constituents of the basaltic rocks making up the Raya valley. The main source of $\mathrm{Mg}^{2+}, \mathrm{Ca}^{2+}, \mathrm{Na}^{+}$and $\mathrm{K}^{+}$ions in the groundwater in the area are inferred to be contributed by the interaction of groundwater with silicate minerals pyroxene, albite, anorthite and potassium feldspar, respectively. Likewise, Nedaw (2003) has reported that $\mathrm{Mg}^{2+}$ and $\mathrm{Ca}^{2+}$ are the most abundant cations followed by $\mathrm{Na}^{+}$in 
the study area. Similarly, Ayenew et al. (2013) found that the dominance of $\mathrm{Mg}^{2+}$ and $\mathrm{Ca}^{2+}$ in the western side of the study area and $\mathrm{Na}^{+}$dominant water type in the valley floor. As discussed by Ayenew et al. (2011); and Gebreegziabher (2012), $\mathrm{Na}^{+}$is dominant in groundwater in central graben especially towards the outlet of the catchment and its concentration reaches up to $11 \%$ of the total cations. Hussein (2011) also indicated that $\mathrm{Na}^{+}$concentration is significant as compared to the other cations in the wells located in the outlet area.

Piper trilinear diagram, plot of the chemical analysis results (Fig 6), indicate that majority of the water samples, in terms of cation, fall in no dominant cation field while, anions fall in bicarbonate field. The combined field designate magnesium bicarbonate as the dominant groundwater type in Raya valley (Fig 6).

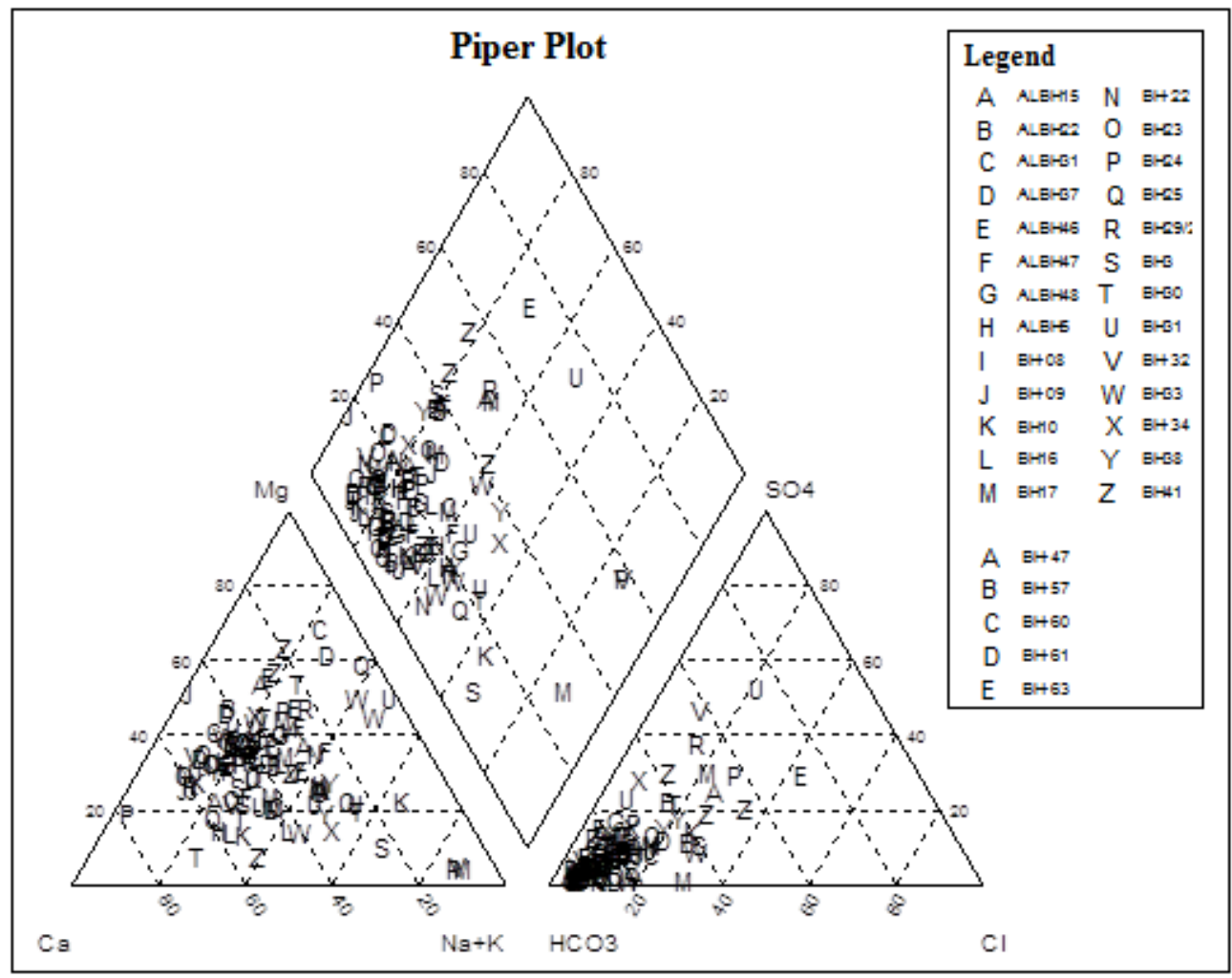

Figure 6. Piper plot showing variation in hydrochemistry for the water samples.

The hydrochemical analysis results indicate that, the origin and geochemical composition of the groundwater in the area is spatially variable because the geologic variations caused spatial variability of the hydrochemical parameters. Identified water types are $\mathrm{Mg}-\mathrm{Ca}-\mathrm{HCO}_{3}, \mathrm{Ca}-\mathrm{HCO}_{3}$, $\mathrm{Mg}-\mathrm{Ca}-\mathrm{Na}-\mathrm{HCO}_{3}, \mathrm{Ca}-\mathrm{Na}-\mathrm{Mg}-\mathrm{HCO}_{3}$, and $\mathrm{Na}-\mathrm{Mg}-\mathrm{Ca}-\mathrm{HCO}$. The geochemical composition of 
the groundwater in the area generally, changes from $\mathrm{Mg}-\mathrm{Ca}-\mathrm{HCO}_{3}$ water type in the western volcanic terrain to $\mathrm{Ca}-\mathrm{Mg}-\mathrm{Na}-\mathrm{HCO}_{3}$ and $\mathrm{Ca}-\mathrm{Na}-\mathrm{Mg}-\mathrm{HCO}_{3}$ type in the valley floor. This variation in the chemical facies can be attributed to cation exchange process with prolonged water-rock interaction following the groundwater flow direction.

\subsection{Suitability of the Groundwater for Drinking Purpose}

Major ions concentrations $\left(\mathrm{Ca}^{2+}, \mathrm{Mg}^{2+}, \mathrm{Na}^{+}, \mathrm{K}^{+}, \mathrm{HCO}_{3}{ }^{-}, \mathrm{SO}_{4}{ }^{2-}\right.$, and $\left.\mathrm{Cl}^{-}\right)$and important physicochemical parameters such as total hardness (TH), $\mathrm{pH}$, electrical conductivity (EC), total dissolved solids (TDS) were used to assess the suitability of the groundwater for drinking purpose. TDS and TH are important parameter of water quality whether it is to be used for domestic purpose or not (WHO, 2011). For the classification of water quality based on TDS values Davies and Dewiest (1966) classification is adopted (Table 2). As per this classification, $95 \%$ of the water samples in the study area are found to be permissible for drinking.). While, for classifying the water quality suitability based on total hardness Sawyer and McCarthy (1967) classification is adopted (Table 3). Accordingly, $46 \%$ of the water samples in Raya valley fall in the very hard water class.

Table 2. Suitability of groundwater for drinking based on TDS (Davies and DeWiest, 1966).

\begin{tabular}{|llc|}
\hline TDS $(\boldsymbol{m g} / \boldsymbol{l})$ & Water class & \% of samples of the study area \\
\hline$<500$ & Desirable for drinking & 64 \\
\hline $500-1000$ & permissible for drinking & 31 \\
\hline $1000-3000$ & Useful for irrigation & 5 \\
\hline$>3000$ & Unfit for drinking and irrigation & None \\
\hline
\end{tabular}

Table 3. Classification of groundwater based on hardness (Sawyer and McCarthy, 1967).

\begin{tabular}{|llc|}
\hline $\begin{array}{l}\text { Hardness } \\
\text { as CaCO3 }\end{array}$ & Water class & $\begin{array}{l}\text { \% hardness water class of } \\
\text { water samples in Raya valley }\end{array}$ \\
\hline$<75$ & Soft & 2 \\
\hline $75-150$ & Moderate hard & 6 \\
\hline $150-300$ & Hard & 46 \\
\hline$>300$ & Very hard & 46 \\
\hline
\end{tabular}

Percentage of the analytical results of the water samples in the study area falling beyond the permissible limits for drinking as compared to Ethiopian standard and WHO are given in table 4. From this table, it can be observed that the groundwater quality is exceeding the guidelines permissible limits of Ethiopian standard by $\mathrm{Mg}^{2+}$ in $49 \%, \mathrm{Ca}^{2+}$ in $33 \%$ and $\mathrm{K}^{+}$in $54 \%$. 
The parameters total hardness, EC and TDS are also exceeding permissible limits of Ethiopian standard in $46 \%, 18 \%$ and $5 \%$ respectively.

Table 4. Water samples (in \%) exceeding limits for drinking (ES261, 2001; and WHO, 2006).

\begin{tabular}{|c|c|c|c|c|c|}
\hline Parameter & $\begin{array}{l}\text { Maximum } \\
\text { permissible } \\
\text { level }(\text { ES261, } \\
\text { 2001) }\end{array}$ & $\begin{array}{l}\text { Maximum } \\
\text { permissible } \\
\text { level }(\mathrm{WHO}, \\
\text { 2006) }\end{array}$ & $\begin{array}{l}\text { \% Sample } \\
\text { exceeding } \\
\text { ES261 } \\
(2001)\end{array}$ & $\begin{array}{l}\text { \% Sample } \\
\text { exceeding } \\
\text { WHO } \\
(2006)\end{array}$ & $\begin{array}{l}\text { Undesirable effect produced } \\
\text { beyond maximum permissible } \\
\text { level (Sharma et al., 2017) }\end{array}$ \\
\hline $\begin{array}{l}\text { TDS } \\
\left(\mathrm{mg} \mathrm{l}^{-1}\right)\end{array}$ & 1000 & 500 & 5 & 36 & $\begin{array}{l}\text { Palatability decreases and may } \\
\text { cause gastrointestinal irritation }\end{array}$ \\
\hline $\begin{array}{l}\text { Hardness } \\
\left(\text { as } \mathrm{CaCO}_{3}\right)\end{array}$ & 300 & 500 & 46 & 46 & $\begin{array}{l}\text { Calcification of arteries. It } \\
\text { may diseases of kidney }\end{array}$ \\
\hline $\mathrm{pH}$ & $7.5-8.5$ & $7.0-8.5$ & & None & Taste effects \\
\hline $\mathrm{Ca}^{2+}(\mathrm{mg} / \mathrm{l})$ & 75 & 75 & 33 & 33 & $\begin{array}{l}\text { concretions in the body such } \\
\text { as kidney or bladder stones }\end{array}$ \\
\hline $\mathrm{Mg}^{2+}(\mathrm{mg} / \mathrm{l})$ & 50 & 30 & 21 & 49 & may have laxative effect \\
\hline $\mathrm{Na}^{+}(\mathrm{mg} / \mathrm{l})$ & 200 & 200 & 4 & 4 & $\begin{array}{l}\text { can increase the risk for } \\
\text { hypertension }\end{array}$ \\
\hline $\mathrm{K}^{+}(\mathrm{mg} / \mathrm{l})$ & 1.5 & --- & 54 & --- & $\begin{array}{l}\text { Elevated blood pressure and } \\
\text { hypertension }\end{array}$ \\
\hline $\mathrm{Cl}^{-}(\mathrm{mg} / \mathrm{l})$ & 250 & 250 & 2 & 2 & $\begin{array}{l}\text { Taste, indigestion, and } \\
\text { palatability are affected }\end{array}$ \\
\hline $\begin{array}{l}\mathrm{SO}^{2-} \\
\left(\mathrm{mg} \mathrm{l}^{-1}\right)\end{array}$ & 250 & 200 & 5 & 6 & $\begin{array}{ll}\text { Causes } & \text { gastrointestinal } \\
\text { irritation } & \\
\end{array}$ \\
\hline $\begin{array}{l}\text { EC } \\
(\text { micro } \mathrm{S} / \mathrm{cm})\end{array}$ & 1000 & 750 & 18 & 39 & $\begin{array}{l}\text { Undesirable taste; gastro- } \\
\text { intestinal irritation; corrosion } \\
\text { or incrustation }\end{array}$ \\
\hline
\end{tabular}

\subsection{Suitability of the Groundwater for Irrigation Purpose}

Irrigation water quality refers to the kind and amount of salts present in the water and their effects on crop growth and development. As described by Wilcox (1995), the most important parameters of irrigation water in determining its quality are: (i) concentration of soluble salts (ii) relative proportion of sodium to other principal cations, and (iii) under some condition, bicarbonate concentration as related to the concentration of calcium plus magnesium. These have been termed as the salinity hazard, sodium hazard, and bicarbonate hazard respectively.

\subsubsection{Salinity}

High salt concentrations influence osmotic pressure of the soil solution and affect the ability of plants to absorb water through their roots (Glover, 1996). However an appropriate evaluation of the water quality prior to its use in irrigation will help in arresting any harmful effect on plant 
productivity and groundwater recharge. Water with high salinity is toxic to plants and poses salinity hazard (Jain et al., 2011).

Westcott and Ayers (1984) indicated that if EC is greater than $3000 \mu \mathrm{S} / \mathrm{cm}$, crop productivity is affected very much, and it is good if EC is less than $250 \mu \mathrm{S} \mathrm{cm}^{-1}$. In the case of high electric conductivity, water intake by plant significantly decreases and hence, the productivity is also considerably reduced. In Raya valley, measured EC of the analyzed water samples varies from 308 to $3800 \mu \mathrm{S} / \mathrm{cm}$ with an average value of $795 \mu \mathrm{S} / \mathrm{cm}$. Based on the classification suggested by Westcott and Ayers (1984), 99\% of the groundwater samples in the Raya valley are below the maximum permissible limit for irrigation use. While, the remaining $1 \%$ of the water samples located in the discharge area of the lower central and south western part of the area are falling in the unsuitable range. The spatial salinity distribution in the study area represented as EC is shown in figure 7.

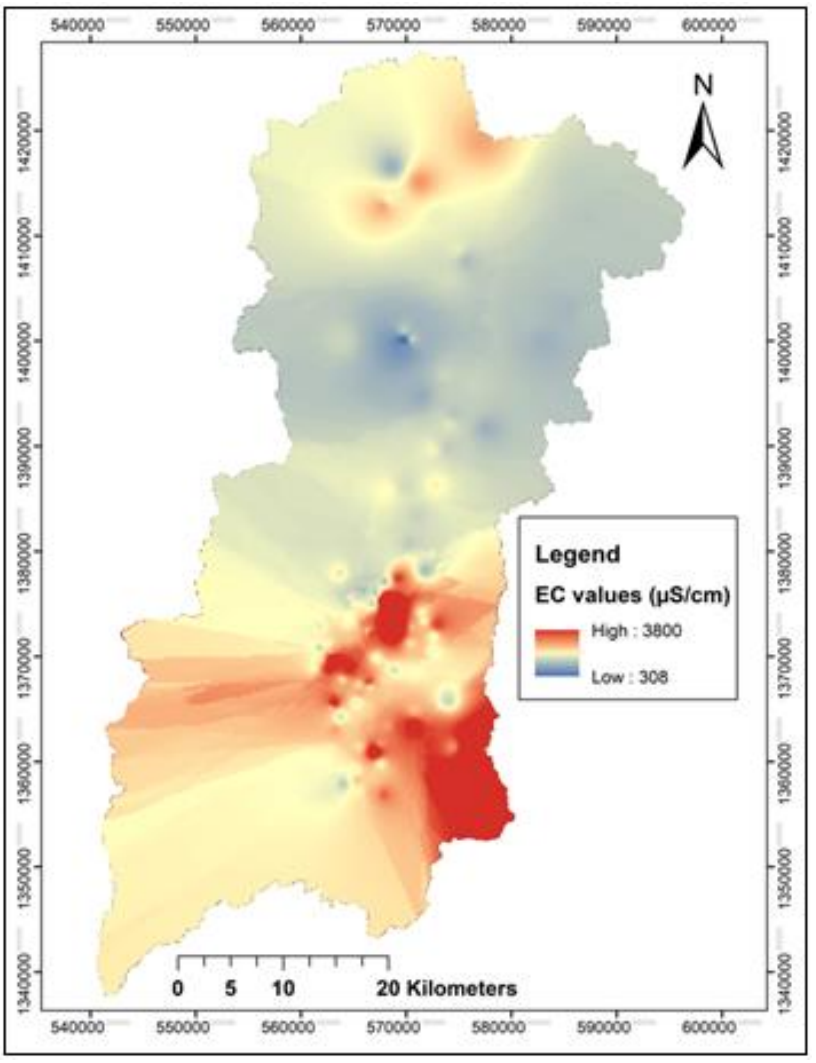

Figure 7. EC distribution of Raya valley.

As it is depicted in the spatial salinity distribution map, groundwater with high EC up to $3730 \mu \mathrm{S} / \mathrm{cm}$ is observed at groundwater discharge areas of the lower central and south eastern 
end of the study area. The high salinity in this part of the study area is resulted due to evaporation of water from the swampy areas of Garjale, Waja- Tumuga and Selienwha swamps.

\subsubsection{Sodicity}

Sodicity is the amount of sodium relative to that of calcium and magnesium. High sodium content leads to the development of alkaline soil. Irrigation with sodium enriched water results in ion exchange reactions which cause aggregates of some soils to break down or disperse, leading to sealing of soil pores and a reduction in the permeability of the soil.

\subsubsection{Sodium (\%)}

In all natural waters, $\mathrm{Na} \%$ is a common parameter to assess its suitability for irrigation purposes since sodium reacts with the soil to reduce permeability (Wilcox, 1955; Janardhana Raju et al., 1992). Excess sodium combining with carbonate, leads to formation of alkali soils, whereas with chloride, saline soils are formed (Wilcox, 1955). According to Wilcox (1955), the sodium percentage $(\mathrm{Na} \%)$ values was obtained by using equation 2 .

$$
\mathrm{Na} \%=\mathrm{Na}^{+} \times 100 /\left[\mathrm{Ca}^{2+}+\mathrm{Mg}^{2+}+\mathrm{Na}^{+}+\mathrm{K}^{+}\right]
$$

(all ionic concentrations are expressed in meq/l)

The sodium percent in the groundwater of Raya valley ranges from 0.9 to $87 \%$ with mean value of $29 \%$. As per the classification of sodium percent class by Wilcox (1995) indicted in table 5, 90\% groundwater samples collected from Raya valley fall in the field of good to permissible. While the remaining $10 \%$ of the water samples, fall in the doubtful to unsuitable ranges which are located in the lower central and south eastern part of the study area.

Table 5. Sodium percent water class (Wilcox, 1955).

\begin{tabular}{|l|l|}
\hline Sodium (\%) & Water quality class \\
\hline$<20$ & Excellent \\
\hline $20-40$ & Good \\
\hline $40-60$ & Permissible \\
\hline $60-80$ & Doubtful \\
\hline$>80$ & Unsuitable \\
\hline
\end{tabular}

\subsubsection{Sodium Adsorption Ratio (SAR)}

SAR is a measure of suitability of water for agriculture/irrigation, because sodium concentration can reduce the soil permeability and soil structure (Todd, 1980; Arveti et al., 2011). Continued use of water with a high SAR value leads to breakdown in the physical structure of the soil. This 
breakdown results in the dispersion of clay soil, causing the soil to become hard and compact when dry and increasingly impervious to water penetration (due to dispersion and swelling) when wet. The sodium adsorption ratio (SAR) is computed using equation 3.

$$
S A R=\frac{N a^{+}}{\sqrt{\frac{1}{2}\left(\mathrm{Ca}^{2+}+M g^{2+}\right)}}
$$

(all ionic concentrations are expressed in meq/lit)

As described in USSL (US Salinity Laboratory) (1954), water having SAR values $<10$ is considered excellent, 10 to 18 good, 18 to 26 as fair, and > 26 unsuitable for irrigation use. The Calculated SAR of the Raya valley ranges from 0.04 to 22 with mean value of 2.4. Based on USSL (US Salinity Laboratory) (1954) SAR classification, 95\% of the analysed groundwater samples in the study area are classified as excellent and suitable for irrigation while, the remaining 5\% are good to fair. As it is depicted in the spatial distribution of $\mathrm{Na} \%$ (Fig 8), there is a localized enrichment in $\mathrm{Na} \%$ in southeastern part while, high zones of SAR are observed in central and northwest of the study area in addition to south eastern part of the catchment.

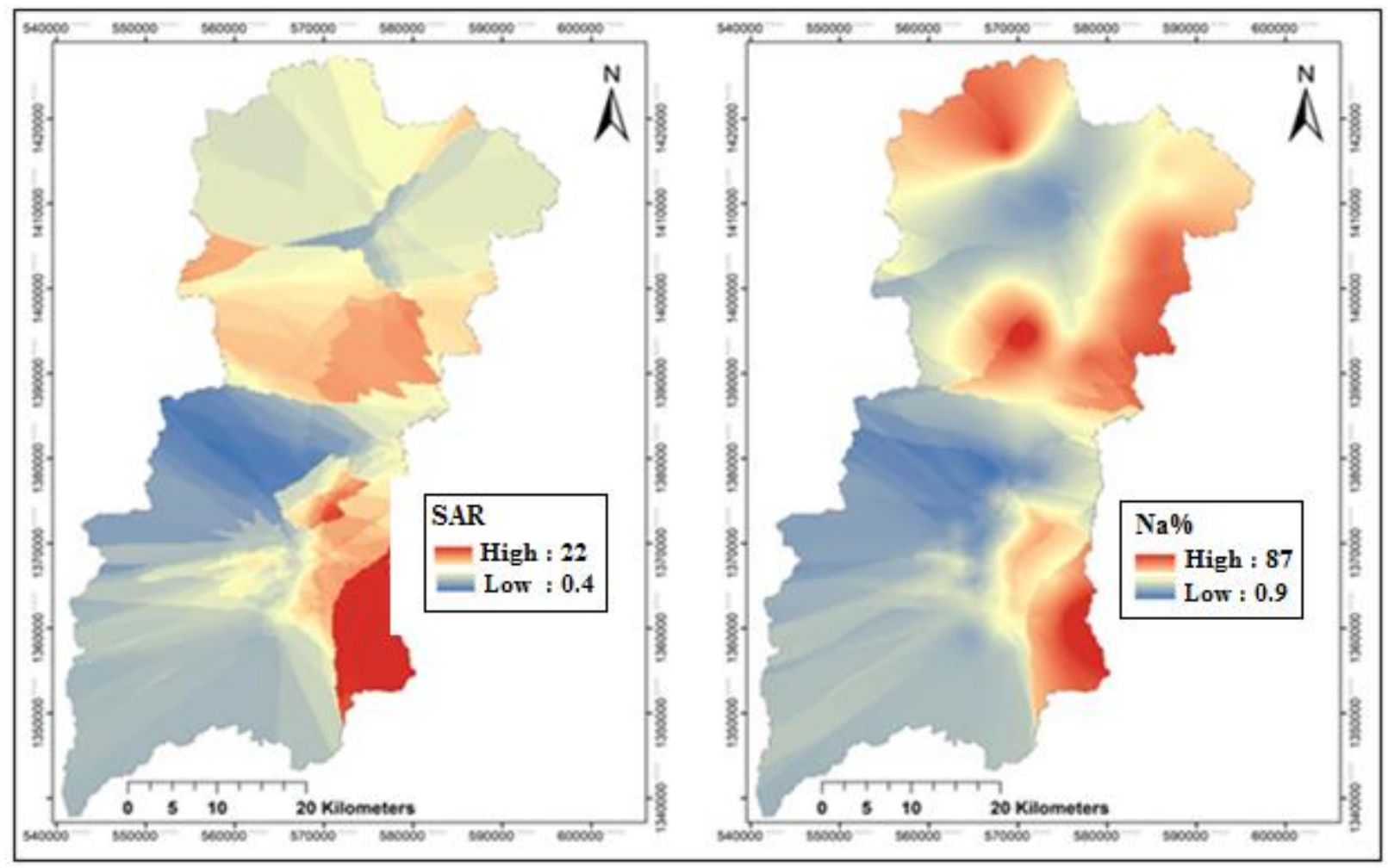

Figure 8. SAR (left) and $\mathrm{Na} \%$ (right) distribution in the study area. 


\subsubsection{Analysis of Sodicity and Salinity Hazards Using Wilcox Diagram}

Wilcox diagram relating sodium percent and total concentration of the analyzed water samples from the study area is shown in figure.9. Based on Wilcox plot $98 \%$ of the groundwater samples of the study area falls in the medium to high salinity range while the remaining $2 \%$ fall under very high salinity range. The outlier values for salinity hazard are observed in the boreholes located around Tumuga swamp and discharge area around the outlet of the catchment and this is possibly due to evapotranspiration of groundwater.

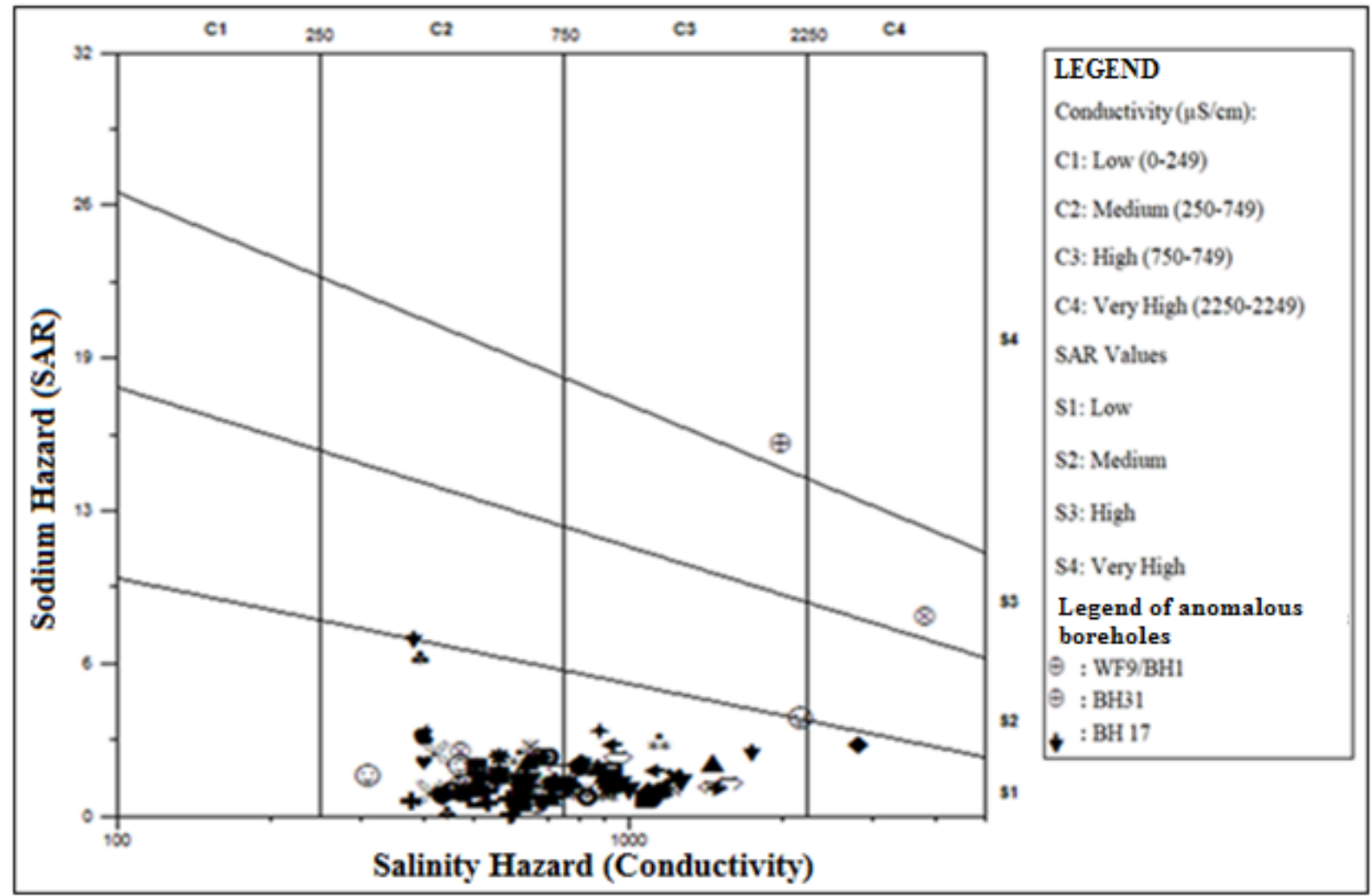

Figure 9. Wilcox diagram of the water samples in the area.

Concerning to sodium hazard, $97 \%$ of the groundwater samples of the study area fall in the low hazard range while, the remaining $3 \%$ fall under high to very high range. Groundwater samples with anomaly of sodium hazard are from the boreholes located around south of Mechare village and Selienwha area where hot water was observed during drilling. Based on the Wilcox diagram classification, groundwater quality in major part of the study area can be considered suitable for irrigation purposes. However, groundwater from the south eastern part of the study 
area is characterized by high salinity and significant sodicity which limits irrigation. Ayenew et al. (2013) based on Wilcox diagram analysis have also drawn similar conclusions.

\subsubsection{Magnesium Ratio}

The index of magnesium hazard (equation 4, all the ions are expressed in meq/l) was developed by Paliwal (1972). High index of magnesium hazard value (greater than 50\%) in irrigation water has an adverse effect on the crop yield as the soil becomes more alkaline (Raghunath, 1987).

$$
\text { Magnesiumratio }=\mathrm{Mg}^{2+} \times 100 /\left(\mathrm{Ca}^{2+}+\mathrm{Mg}^{2+}\right)
$$

In the study area, the Magnesium ratio ranges from 9.5 to $96 \%$ with mean value of $46 \%$. Magnesium ratio results from this study showed that $90 \%$ of the samples are well below $50 \%$ and suitable for irrigation. While, the remaining $10 \%$ are above $50 \%$ and thus have an adverse effect on the crop yield as the soil becomes more alkaline.

\subsubsection{Permeability Index (PI)}

As discussed by Pradesh et al. (2015), permeability index takes into consideration the $\mathrm{Na}^{+}, \mathrm{Ca}^{2+}$, $\mathrm{Mg}^{2+}$ and $\mathrm{HCO}_{3}{ }^{-}$contents of the soil. The permeability index (Equation 5) was developed by Doneen (1964) for assessing the suitability of water for irrigation in terms of permeability index.

$$
P I=\frac{\mathrm{Na}^{+}+\sqrt{\mathrm{HCO}_{3}^{-}}}{\mathrm{Ca}^{2+}+\mathrm{Mg}^{2+}+\mathrm{Na}^{+}} \times 100
$$

(all ions are expressed in meq/l)

According to Doneen (1964), groundwater with PI value of greater than $75 \%$ is categorized in Class I which indicates excellent quality of water for irrigation, values ranging between 25 and $75 \%$ are categorized in Class II that indicates good quality of water for irrigation and Class III is with values less than $25 \%$ indicates that the unsuitable nature of water for irrigation. PI values in the study area vary from 13 to 71 with mean value of $34 \%$. Based on the PI values, $85 \%$ the samples fall in Class II and the remaining $20 \%$ fall in Class III. This makes the groundwater of the area moderately suitable for irrigation.

\section{CONCLUSIONS}

The dominant water types identified from the hydrochemistry analysis of the groundwater samples in Raya valley are $\mathrm{Mg}-\mathrm{HCO}_{3}$ and $\mathrm{Ca}-\mathrm{Na}-\mathrm{HCO}_{3}$ type. Hydrochemistry of groundwater is changing from dominant $\mathrm{Mg}-\mathrm{Ca}-\mathrm{HCO}_{3}$ in the in the western volcanic terrain to $\mathrm{Ca}-\mathrm{Mg}-\mathrm{Na}-\mathrm{HCO}_{3}$ 
and $\mathrm{Ca}-\mathrm{Na}-\mathrm{Mg}-\mathrm{HCO}_{3}$ in the alluvial deposits of the valley floor. This is interpreted as cation exchange process with prolonged water-rock interaction following groundwater flow direction.

On the basis of total hardness classification, $46 \%$ of the water samples in Raya valley fall in the very hard water class. While, classification based on TDS values indicate that $95 \%$ of the water samples in the study area are found to be permissible for drinking. The groundwater

quality for drinking is exceeding the guidelines permissible limits of Ethiopian standard by $\mathrm{Mg}^{2+}$ in $49 \%, \mathrm{Ca}^{2+}$ in $33 \%$ and $\mathrm{K}^{+}$in $54 \%$ of analyzed water samples. The parameters of the analyzed water samples, total hardness, EC and TDS are also exceeding permissible limits of Ethiopian standard for drinking in $46 \%, 18 \%$ and $5 \%$ respectively. Water quality assessment for irrigation suitability based on $\mathrm{Na} \%, \mathrm{SAR}, \mathrm{Mg}$ ratio and $\mathrm{PI}$ indicate that the groundwater fall in the range of good to permissible however, higher salinity, sodicity hazard and low permeability index restricted its suitability mainly at south central and south eastern discharge areas of the study area. Wilcox diagram showed that $98 \%$ of the analysed groundwater samples of the study area fall in the medium to high salinity range while $97 \%$ of the groundwater samples of the study area fall in the low sodium hazard range.

The conclusions drawn on the suitability of groundwater for irrigation in the present study is based on water quality parameters which are empirical. It would be better for future studies to consider other factors like soil type, crop type, crop pattern, frequency and recharge (rainfall), climate etc in evaluating the suitability of groundwater for irrigation.

\section{ACKNOWLEDGEMENTS}

The authors are grateful for the support provided by Mekelle University for providing the necessary support and funding to conduct the research. We are grateful to the two anonymous referees for constructive comments on an earlier version of this manuscript.

\section{REFERENCE}

Anderson, M. P \& Woessner, W. W. 1992. Applied groundwater modeling: simulation of flow and advective transport. San Diego Academic Press.

Arveti, N., Sarma, M. R. S., Aitkenhead-Peterson, J. A \& Sunil, K. 2011. Fluoride incidence in groundwater: a case study from Talupula, Andhra Pradesh, India. Environ Monit Asses 172:427-443. 
Ayenew, T., Gebreegziabher, M., Kebede, S \& Mamo, S. 2013. Integrated assessment of hydrogeology and water quality for groundwater- based irrigation development in the Raya Valley, northern Ethiopia. http://doi.org/10.1080/02508060.2013.821640.

Ayenew, T., Mamo, S., Ali, S., Abdu, A., Gebreegziabher, M \& Desalegn, A. 2011. Hydrogeological and groundwater potential evaluation, water quality assessment and socioeconomic surveying for small-scale irrigation development in the Raya-Kobo Valleys, Northern Ethiopia. Report to the International Water Management Institute, Addis Ababa, Ethiopia.

Azpurua, M. A \& Ramos, K. D. 2010. Comparison of Spatial Interpolation Methods for Estimation of Average Electromagnetic Field Magnitude. Progress in Electromagnetics Research M, 14 (August), pp. 135-145 (doi: 10.2528/PIERM10083103).

Davies, S \& De Wiest, R.J.M. 1966. Hydrogeology. Wiley, New York.

Doneen, L. D. 1964. Notes on water quality in agriculture. Water Science and Engineering, University of California, Davis.

Ethiopian Standard (ES 261). 2001. Ethiopian Drinking Water Quality Standard $2^{\text {nd }}$ edition, Addis Ababa, Ethiopia.

Fetter, C.W. 2001. Applied hydrogeology + Visual Modflow, Flownet and Aqtesolv student version software on CD ROM. Prentice Hall, Upper Saddle River, 597p.

Freeze, R. A \& Cherry, J. A. 1979. Groundwater. Prentice-Hall, Inc, Englewood Cliffs, New Jersey, 604p.

Gebreegziabher, M. 2012. An Integrated Hydrogeological study to understand the groundwater flow dynamics of Raya Valley Basin, Northern Ethiopia: Hydrochemistry, Isotope Hydrology and Flow Modeling Approaches. Master's Thesis, Addis Ababa University, Ethiopia (unpubl.).

Hailu, A. 2010. Aquifer Characterization of the Raya Valley based on pumping test and geophysical data analysis, Northern Ethiopia. Master's Thesis, Addis Ababa University, Ethiopia (unpubl.).

Hounslow, A. W. 1995. Water quality data: analysis and interpretation. CRC Press, Florida.

Hussein, A. 2011. Quantitative status, vulnerability and pollution of groundwater resources in different environmental and climatic contexts in Sardinia and in Ethiopia. $\mathrm{PhD}$ thesis, Earth Science, Universita degli Studi di Cagliari, Italy. 
Jain, M. K., Dadhich, L. K \& Kalpana, S. 2011. Water quality assessment of Kishanpura Dam, Baran, Rajasthan, India. Nat. Environ. Poll. Tech., 10:405-408.

Janardhana Raju, N., Reddy, T. V. K., Kotaiah, B \& Nayudu, P. T. 1992. A study on seasonal variations of groundwater quality in upper Gunjanaeru River basin, Cuddapah District, Andhra Pradesh. Fresenius Environ. Bull., 1:98-103.

Maucha, R. 1940. The graphic symbolization of the chemical composition of natural waters, Hiderol, Kozlony, pp 29-30.

Mohammed sultan, A. H. 2010. Groundwater flow modelling assisted by GIS and RS techniques (Raya Valley Ethiopia). Ph.D Thesis, International Institute for Geo-information Science and Earth Observation, Enschede, the Netherlands (unpubl.).

Nedaw, D. 2003. Aquifer characterization and Hydrochemical investigation of Raya Valley, Northern Ethiopia. Ph.D Thesis, Institutes of Applied Geology, University of Natural Resources and Applied Life Sciences (BOKU), Vienna.

Paliwal, K. V. 1972. Irrigation with saline water). Monogram No. 2 (new series). IARI, New Delhi, 198p.

Patil, P. R. 2010. Suitability assessment of groundwater for irrigation and drinking purpose in the northern region of Jordan. J. Environ. Sci. Tech., 5:274-290.

Piper, A. M. 1953. A graphic procedure in the geo-chemical interpretation of water analysis. USGS, groundwater note no. 12.

Pradesh, U., Singh, Raju, N. J \& Ramakrishna, C. 2015. Evaluation of Groundwater Quality and its Suitability for Domestic and Irrigation Use in Parts of Chandauli-Varanasi, 572-587.

Raghunath, H. M. 1987. Groundwater. Wiley Eastern Ltd., New Delhi, pp 344-369.

Relief Society of Tigray, REST 1996. Raya Valley Development Study Project: Phase I Reconnaissance phase report, Volume 1, Main report, Alamata.

Sawyer, G. N \& McCarthy, D. L. 1967. Chemistry of sanitary Engineers, $2^{\text {nd }}$ Edition, McGraw Hill, 518p.

Sharma, D. A., Rishi, M. S \& Keesari, T. 2017. Evaluation of groundwater quality and suitability for irrigation and drinking purposes in southwest Punjab, India using hydrochemical approach. Applied Water Science, 7(6):3137-3150 (doi: 10.1007/s13201-016-0456-6).

Stiff Jr., H. A. 1940. The interpretation of chemical water analysis by means of patterns. Journal of Petroleum Technology, 3:15-16. 
Tadesse, N., Nedaw, D., Woldearegay, K., Gebreyohannes, T \& Steenbergen, F.V. 2015. Groundwater management for irrigation in the Raya and Kobo valleys, Northern Ethiopia. International Journal of Earth Sciences and Engineering, 8(3):1104-1114.

Tesfaye, S., Harding, D. J \& Kusky, T. M. 2003. Early continental breakup boundary and migration of the Afar triple junction, Ethiopia. Bulletin of the Geological Society of America, 115(9): 1053-1067.

Todd, D. K. 1980. Groundwater hydrology: $2^{\text {nd }}$ Edition, Wiley, New York, 535p.

USSL (US Salinity Laboratory). 1954. Diagnosis and improvement of saline and alkali soils. US Department of Agriculture Hand Book, No. 60.

Venkateswaran, S., Vijay Prabhu, M., Mohammed Rafi, M \& Vallel, L. K. 2011. Assessment of groundwater quality for irrigational use in Cumbum Valley, Madurai District, Tamil Nadu, India. Nat. Environ. Poll. Tech., 10:207-212.

Water Work Design and Supervision Enterprise (WWDSE). 2008. Geological investigation report on Raya valley, Northern Ethiopia. Report (upubl.).

Westcott, D. W \& Ayers, R. C. 1984. Water quality criteria in irrigation with Reclaim municipal wastewater: state water resources control board Sacramento, California.

WHO. 2006. Guidelines for drinking water quality, volume 1 , Recommendations, $3^{\text {rd }}$ edition, World Health Organization, Geneva.

WHO. 2011. Guidelines for drinking water quality. World Health Organization, Geneva

Wilcox, L.V. 1955. Classification and use of irrigation waters, US Dept. of Agriculture, 19p.

Zaporozhe, A. 1972. Graphical interpretation of water quality data. Groundwater, 10:32-43. 